V. 13 N. 2

MAIO-AGO 2017

ISSN 2317-6172

Recebido: 12.02 .2015

Aprovado: 05.05.2017

DOI: http://dx.doi.org/10.1590/2317-6172201723

Federal University of Rio de Janeiro (UFRJ) Rio de Janeiro - RJ - Brazil

2 Federal University of Rio de Janeiro (UFRJ) Rio de Janeiro - RJ - Brazil

\section{Law, institutions, and interpretation in Jacques Derrida}

DIREITO, INSTITUIÇÕES E INTERPRETAÇÃO EM JACQUES DERRIDA

\author{
Juliana Neuenschwander Magalhães ${ }^{1}$ \\ e José Antonio Rego Magalhães ${ }^{2}$
}

\title{
Abstract
}

In this paper, we would like to advocate for a certain reading of Jacques Derrida's thinking about law, against the grain of most of his reception in legal studies. In this process, we aim to develop a better theoretical understanding of the dynamics of how law institutes itself, and continues to function as an institution, through interpretive practices that must, on one side, respect the rules of the institution and, at the same time, re-institute it on new grounds, as Jacques Derrida points out in his lecture "Force of Law: The 'Mystical Foundation of Authority." The problem under investigation is how law manages to differentiate itself symbolically from violence and what are the consequences of this concerning legal interpretation. This paper's partial conclusion is that ultimately we are better off viewing interpretation as neither fully determined by nor fully free from text and/or context.

\section{Keywords}

Interpretation; violence; institutions; deconstruction; critical theory.

\section{Resumo}

Neste artigo, gostaríamos de defender uma certa leitura do pensamento de Jacques Derrida sobre o direito, a contrapelo da maioria da sua recepção nos estudos jurídicos e, nesse processo, desenvolver um melhor entendimento teórico da dinâmica de como o direito se institui e continua a funcionar como instituição, através de práticas interpretativas que devem, de um lado, respeitar as regras da instituição e, ao mesmo tempo, reinstituí-la em novas bases, como aponta Jacques Derrida no seu texto "Força de Lei: o 'Fundamento Místico da Autoridade'". O problema sob investigação é como o direito pode diferenciar-se simbolicamente da violência, e quais as consequências disso no que tange à interpretação legal. A conclusão parcial deste artigo é que, finalmente, ganhamos mais vendo a interpretação como nem inteiramente determinada por, nem inteiramente livre de texto e/ou contexto.

\section{Palavras-chave}

Interpretação; violência; instituições; desconstrução; teoria crítica.

\section{(cc) BY-NC}




\section{INSTITUTION}

The term "deconstruction," which most of us have probably heard or read about (though not necessarily in its strict philosophical use), entered the philosophical, literary, and political vocabulary through the work of the French philosopher Jacques Derrida (though it existed before that, at least in grammatical and architectural jargon). The term, current of thought or "method" (though Derrida frequently asserted that it should not be simply considered a method) met wide institutional acceptance during the 1970s and 1980s, especially in the United States, when "critical theory" became widespread in literary studies, in the form of Marxist, feminist, African American and other critical movements. It became widespread also in legal studies, especially through the Critical Legal Studies movement in the United States and their equivalents in the UK - movements that were also indebted to actualized versions of Marxism and concerned with the demands of subaltern groups such as women, ethnical minorities and LGBT.

In Brazil, Derrida's thought was introduced, first, in literary studies, by readers such as Silviano Santiago and Evando Nascimento, and more recently in departments of Philosophy, mainly through the work of Paulo César Duque-Estrada. It has, therefore, some degree of institutional reception in those fields. In legal studies, though, a tradition of "deconstructive" legal thinking remains yet to be instituted in Brazil, even if some professors like Katya Kozicki and Bethania Assy, without being part of a movement - but in contact with American and British developers of Derrida's thought - have taken his work into academic discussion.

Some might raise the hypothesis that the introduction of Derrida's thought in Brazilian academic institutions would not make sense today; that its moment has passed; that it would be now belated, extemporary. After all - philosophical arguments aside -, deconstruction is taken to be a 1980 s fashion; it may be, today, passé. Against that hypothesis, we would argue, first, that, as some (in our opinion, more rigorous) readers of Derrida have argued (cf. DE VILLE, 2011; CRITCHLEY, 2008), the reception of his contribution, during the "deconstruction" hype, was in many ways superficial. For that reason, Derrida's thought was either caricaturized (as was the case with part of "critical theory" and Critical Legal Studies, where deconstruction was considered "the absolute impossibility of any meaning") or domesticated (in the case of more politically "liberal" legal thinkers). We would like to argue that, hype being taken out of the equation, Derrida's heritage (and let's just set aside the term "deconstruction," as Derrida himself always found its excessive popularity unfortunate) is yet to be received, not only in Brazilian legal academy, but in legal studies in general, since the deeper and more particular consequences of Derrida's writing have not yet been brought to influence legal thinking as they potentially could.

Secondly, we would like to demonstrate, throughout this paper, that Derrida's thinking about law, especially when it thematizes the unstable relations between law and violence, 
is today more pertinent than ever, as we come to see more and more clearly, in Brazil and elsewhere, how the relations between law, force, violence, authority, justice, etc., are far more complicated than most of the available theorizations of law are able to construe them. ${ }^{1}$ We believe - to express it naively - that, when there is complication, paradox, and instability, it is better to acknowledge the fact than to hide it behind a superficially coherent theory. Derrida's thought is one that allows paradox and instability to show through, in a way that permits law's obliterated relations with violence to be thematized in richer, more consequent ways.

In order, then, either to re-institute the terms in which deconstruction has been received in legal academic institutions, or just to institute a "new" discussion of Derrida's thought in that field (and, as we shall see, for Derrida it is never possible to clearly separate these two hypotheses), we propose in this paper to question, precisely, the problem of institution, of the institution of law as an institution, and therefore the ambiguity between the two meanings of the word "institution" itself: the act of institution of that which is instituted (founded), and the institution as structure that, having been founded, maintains itself in a duration. This relation between foundation, conservation, and finally destruction is, as we shall see, where the complex relations between law and violence are brought forward to show their paradoxical nature.

\section{INTERPRETATION VERSUS AFFIRMATION}

As Jacques Derrida himself acknowledges in his book Force of Law, the "mystical foundation of authority", deconstruction has long been the object of a certain suspicion, especially when brought into the field of legal studies:

Isn't it because, as certain people suspect, deconstruction doesn't in itself permit any just action, any just discourse on justice but instead constitutes a threat to droit, to law or right, and ruins the conditions of every possibility of justice? (DERRIDA, 1992, p. 4).

This suspicion seemed to arise from a particular interpretation of deconstruction which, based mainly on Derrida's early texts such as "Structure, sign and play" (1967), tended to identify it with a quasi-nihilistic affirmative type of interpretation, which would tend

1 We refer here, for instance, to the events of June 2013 in Brazil and their aftermath, culminating in what many have (controversially) called a "parliamentary coup d'état" in the present year of 2016, as well as the recent worldwide tradition of street protests that preceded those events. This new wave of political unrest, as well as the many exceptional apparatuses that have been mobilized in order to control it, seem to have brought to focus, once again, the ambiguous relation between law and violence. 
to forcefully impose the interpreter's will over the text. ${ }^{2}$ This interpretation of Derrida's work seemed useful - especially, of course, for critical legal thinkers with politically charged intentions - for criticizing law from an "external" point of view, by showing it as based on certain conceptual distinctions that, when destabilized, would then let law show through as just a structure of oppression used by dominant political forces "outside" of it as an instrument to their ends. On the other hand, deconstruction would be useless for thinking about law from an "internal" point of view or about justice.

In "Force of law," Derrida (1992) goes a long way to counter this suspicion, by arguing that deconstruction does not simply render justice (or the application of justice through law) impossible. It does feature justice as impossible, but not as simply so. Justice, like deconstruction itself, is shown as both impossible and possible at once. It is precisely that, according to Derrida, which allows the concept of justice to open law up to its outside, and so prevents it from becoming a simple self-identical, self-enforcing machine. If justice were just possible, it would already be in the field of justice as law, and thus could not serve to mitigate law's self-imposing violence. If it were just impossible, on the other hand, it would be unable to interfere with law.

In this process, Derrida, as we are going to argue, brings into sharper focus a frequently obscured aspect of deconstruction - that it does not function always just as play or affirmation, but in a constant sliding between moves of affirmation and of negotiation with the rational, the calculable, the traditional interpretive canons and the established institutions. In this sense - and this is what we will be thinking about in the most part of this paper -, Derrida's work would be neither what critical/Marxist thinkers would want (a hammer able to destroy established structures of power), nor what more "liberal" lawyers would prefer (a thinking about law and justice that could easily be accommodated by liberal-democratic institutions), but yet something else.

Years before Derrida wrote "Force of Law," Sam Weber (2001) called attention to this more complex aspect of deconstruction, against the reduction of Derrida's "interpretation of interpretation" to mere affirmation. ${ }^{3}$ This might be one of the reasons why Derrida (1992, p. 14), in his paper, seems to pay tribute to Weber as a predecessor to the kind of point he is making about the relations between law, force, and interpretation. Stanley Fish - whose view of interpretation also questions the binary opposition between freedom and constraint - is also mentioned in the same passage, in which Derrida, after a long

2 We should emphasize here that we do not subscribe to that interpretation of "Structure, sign and play," and only present it here in order to situate the double bind out of which the interpretation we consider more accurate can emerge.

$3 \quad$ Weber's book was originally published in 1987. 
discussion based on quotations from Pascal and Montaigne, brings his reading of those texts into a contemporary context:

These texts by Montaigne and Pascal, along with the texts from the tradition to which they belong and the rather active interpretation of them that I propose, could be brought into Stanley Fish's discussion in "Force” (DoingWhat Comes Naturally) of Hart's Concept of Law, and several others, implicitly including Rawls, himself criticized by Hart, as well as into many debates illuminated by certain texts of Sam Weber on the agonistic and not simply intra-institutional character of certain conflicts in Institution and Interpretation.

Derrida (1992, p. 14), in this part of his discussion, is interested in the problem of how law founds itself, and particularly in the phrase "mystical foundation of authority" used by Montaigne and reproduced by Pascal, which Derrida actively interprets in what he calls "a rather Wittgensteinian direction." Derrida, thus, calls attention to the way in which neither law nor force can have any precedence (causal, temporal, hierarchical) over each other, since they are both founded in a same "mystical" moment, in a "performative tautology" (DERRIDA, 1992, p. 33). This "performative tautology" makes itself interpretable as legitimate only in retrospect, by the use of interpretive canons that are themselves instituted in the "mystical" moment of foundation, but that in its moment of institution is "neither legal, nor illegal" (DERRIDA, 1992, p. 6). In this discussion, the relations between law and violence are shown to be much more ambiguous and complicated than any proper, traditional theory of law - that would take law as its object only after its foundational moment and in a retrospective relation to it - could show them to be. This is the context in which Derrida suggests the cited texts by Pascal and Montaigne could be "brought into" the contemporary discussions of Fish and Weber.

In "Force," Fish problematizes H. L. A. Hart's attempt at guaranteeing a distinction between law (as a rule-governed system of coercion) and mere violence (as in his famous example of a criminal who issues a command while pointing a gun at his victim). In Institution and interpretation, Weber also describes how any institution, in order to posit itself as such, must necessarily generate an exclusion (for example, law, in order to be law, must differentiate itself from violence). In this respect, both authors seem to prepare a reading of Derrida himself in which the idea of institution (in the double sense used by Weber of both the act of foundation and the system produced by such an act) plays an important role in interpretation.

\section{INSTITUTION, DESTRUCTION, DECONSTRUCTION}

It is sometimes forgotten that the word "deconstruction" was designed, from the very beginning (in Derrida's translation of Heidegger), to set itself apart from mere destruction. 
In fact, the word is particularly interesting because it does not only bear the prefix "de," indicating separation, but also its opposite “con," indicating union. Every gesture of deconstruction, as it brings apart some discourse or structure, must also at the same time bring it together in some new configuration. Not only deconstruction is different from simple destruction, but also the very possibility of pure destruction is deeply problematized in Derrida's thought, as we will see, in a very strong example, in his discussion of Walter Benjamin's critique of violence.

Because deconstruction does not attack from outside - a move that would presuppose some kind of solid stance from which to launch itself - , but from the inside of the institutions it intends to destabilize, it can never simply do away with the institution as a whole, but must negotiate with its internal structures, conceding just as much as it is able to reject. It does, of course, always involve a measure of rupture and destruction, but never purely. The following passage of Force of law is representative:

Can what we are doing here resemble a general strike or a revolution, with regard to models, structures but also modes of readability of political action? Is that what deconstruction is? Is it a general strike or a strategy of rupture? Yes and no. Yes, to the extent that it assumes the right to contest, and not only theoretically, constitutional protocols, the very charter that governs reading in our culture and especially in the academy. No, at least to the extent that it is in the academy that it has been developed (and let's not forget, if we do not wish to sink into ridicule or indecency, that we are comfortably installed here on Fifth Avenue - only a few blocks away from the inferno of injustice). And besides, just as a strategy of rupture is never pure, since the lawyer or the accused has to "negotiate" it in some way before a tribunal or in the course of a hunger strike in the prison, so there is never a pure opposition between the general political strike looking to re-found another state and the general proletarian strike looking to destroy the state. (DERRIDA, 1992, p. 38).

In this passage, Derrida is referring to a distinction that Benjamin (2011) takes from Sorel (1972) - the distinction between two types of general strike: "political" and "proletarian". In Benjamin, that distinction is parallel to the one between the violence that institutes and conserves law (which Benjamin calls "mythical") and the "pure" violence that destroys law and the state without founding a new law or a new state in their place (which Benjamin calls "divine" violence). The German word translated here as "violence," "Gewalt" is important in understanding what is in question here. It can also be translated as "force", as well as "power" in the sense of legitimate power, as "legitimate authority." The whole problem here could be summed up in the ambiguity of that word - the undecidable ambiguity between violence and legitimate power in the "mystical" moment of law's foundation. 
While Benjamin's hopes seem to be deposited in the possibility of his "divine" violence - that is, that law be done away with "for good" -, Derrida seems clearly suspicious of that possibility. In his deconstructive reading of Benjamin's critique of violence, no pure rupture remains possible, as well as no pure continuity. In Derrida's way of thinking, there is never any guarantee against the imposition of authoritarian violence, and only relentless vigilance can serve to mitigate that menace.

The distrust shown by Derrida in the face of Benjamin's project of pure rupture (which is related to the proposal of an equally pure language, entirely differentiated from the language of signs and communication) is such that Derrida relates it to the dangerous anti-Aufklärung wave that, according to him, is in the root of "the worst" - Nazism. In fact, if we think of the connotation the expression has acquired after Benjamin's death, it is easy to understand Derrida's suspicion against any project of a final solution to the problem of law, of the state, of violence, or any other. It is true that most projects in history that envisioned to finally solving the problems of humanity have eventually degenerated into violence.

It must be noted, though, that Derrida's complication between rupture, institution, and conservation does not imply taking rupture out of the equation. Rupture must be inscribed in continuity if continuity is to be conceived as iterability - that is, as the repetition of the same not as same, but as other. In fact, Derrida (1992, p. 37) calls the "political" and the "proletarian" general strikes (the institution of a new state and the destruction of the state - the word "state" here expanding to a much broader sense) "the two temptations of deconstruction." The word "temptations" deserves attention, since it does not imply either simple adherence or simple rejection. That which tempts and remains as a temptation is that which one desires but is not ever able (by fact or by right) to fully have. No pure rupture with the present state, and no pure institution of a state (which would always risk, if deprived of any aspect of rupture, to mean the re-institution of the same state) are available as such to deconstruction, and yet deconstruction tends to both, desires both. It perpetually slides between both sides, but achieves none.

Therefore, as we see in the following passage, rupture and destruction are always a necessary moment of deconstruction, even if they are never pure:

We might say then that there is a possibility of general strike, a right to general strike in any interpretative reading, the right to contest established law in its strongest authority, the law of the state. One has the right to suspend legitimating authority and all its norms of reading, and to do this in the most incisive, most effective, most pertinent readings, which of course will sometimes argue with the unreadable in order to found another order of reading, another state, sometimes not. (DERRIDA, 1992, p. 37). 
Therefore, as we began by distinguishing deconstruction from mere affirmation, and then proceeded to prevent it from excluding affirmation (by excluding the possibility of rupture), we now find ourselves dealing with a version of deconstruction that is - as, of course, it should be - in an unstable state of play between contradictory aspects. In this version of deconstruction, as we are caught in an alternation of institution, conservation and rupture, the idea of the institution - in the sense of that order which has been, at some point, instituted, in a rupture with previous orders, and now seeks to maintain itself - acquires great importance, for it is always in relation to some established order, to some state, law, or institution in general, that any conservation, rupture or foundation - and so any deconstruction - may take place.

\section{Finding AND INVENTING LAW}

In a lecture given in Washington D.C. before his death, at the Library of Congress, under the title "Is there truth in interpretation? Law, literature and history," Ronald Dworkin (2009) gave the following definition of interpretation:

I'm suggesting that we think of interpretation in the following way: the true interpretation of an object, a poem, a painting, a provision of the constitution, is the reading of that which best acquits the responsibility of interpreters given by the best interpretation of the practice they have joined. Interpretation is multiply interpretive. It's interpretive all the way down.

Let aside the question of responsibility and of the possibility of defining the "best interpretation" of a practice - themes that we will not have the time to discuss here -, what is of interest in this passage is the very informal expression (but one that Dworkin repeats once again at the very ending of his lecture) that interpretation "is interpretive all the way down." What does that mean?

Dworkin is not only saying that the object of interpretation cannot be known without interpretation, but also that the practice of interpretation itself can only be engaged in through an interpretation of that practice. Saying that interpretation is interpretive all the way down points to a project of making interpretation stand on its own, without footing on any non-interpretive basis - be it the subject, the object or the practice itself. This project brings Dworkin close to thinkers in the continental tradition such as Gadamer (1999) and even Derrida - even if Dworkin never explicitly commented much on such influences, and even if, of course, his thought is very distant, in many senses, from that of both thinkers (and particularly Derrida).

In Law's empire, Dworkin (1986, p. 225) writes that his theory of "law as integrity rejects as unhelpful the ancient question whether judges find or invent law", affirming 
that in some sense "they [the judges] do both and neither" as they must "interpret contemporary legal practice seen as an unfolding political narrative."Through this Aufhebunglike movement of leaving behind a distinction in order to reconfigure the whole question, Dworkin seems set to leave behind both subject-centered (invention-related) and object-centered (finding-related) models of interpretation in favor of a practice (play?) that cannot itself be pinned down in any non-interpretive way. In his first detailed treatment of the question, in the essay "Law as interpretation," Dworkin (1982, p. 527) argues, already in the same sense, that "legal practice is an exercise in interpretation not only when lawyers interpret particular documents or statutes, but generally," that is, all the way down.

However, does the structure of Dworkin's theory live up to this promise of a thoroughly interpretive theory of interpretation? Stanley Fish argues otherwise. In a response to Dworkin's last mentioned essay, Fish (1989, p. 86) contends that, even though Dworkin is concerned to describe legal interpretation "in such a way as to avoid claiming either that in deciding a case judges find the plain meaning of the law 'just there' or, alternatively, that they make up meaning 'wholesale' in accordance with personal preference or whim" (a dualism that Fish associates respectively with legal positivism and realism), he "repeatedly falls away from his own best insights into a version of the fallacies (of pure objectivity and pure subjectivity) he so forcefully challenges." We will not be able to go into the details of Fish's arguments against Dworkin in this paper and, for the moment, it is enough to say that, for him, it is a feature of the very structure of interpretation in general that participants are always both free and constrained by the set of practices available as possible in a given interpretive community. According to Fish (1989, p. 97), "interpretation is a structure of constraints, a structure which, because it is always and already in place, renders unavailable the independent or uninterpreted text and renders unimaginable the independent and freely interpreting reader" (notice the very Heideggerian “always already," which also appears often in Derrida).

In such a picture of legal interpretation (one that seems to correspond to the wishes of both Fish and Dworkin, even if the former believes the latter to have failed in his effort to achieve it), all interpretative practice is shown as both free and constrained; as both concerned with finding the meaning "in the text" and with creating or inventing it anew, and yet neither purely one thing nor the other.

In "Structure, sign and play," Derrida (1967) presents two versions of interpretation - one in which interpretation is seen as hermeneutic and nostalgic, seeking to retrieve the meaning in the interpreted object, and another in which it is seen as a play that is not concerned with finding any truth, but in affirming it over the object. This distinction seems to parallel quite neatly the one we have been dealing with. On one side, we have the object constraining the interpreter in his interpretation; on the other, it is the subject that freely attributes meaning over a text that, in itself, has no retrievable meaning. 
In much of his reception (especially in fields outside of philosophy, such as literature and law, where he was widely received in the United States), Derrida's image has been mostly associated, both by followers and detractors, to the side of play and affirmation. In his essay "Closure and exclusion", though, Samuel Weber (2001, p. 3) argues that, as Derrida describes these "two interpretations of interpretation," he does not put himself on the side of play and against nostalgic interpretation, but actually adopts a third type of interpretation that is, itself, a play between the two previous ones. "There are not simply two antagonists engaged here," Weber writes, “- nostalgic versus affirmative interpretation but a third, the interpretive gesture of Derrida's text itself, setting the scene of a struggle it seems only to describe."

According to Weber (2001, p. 5):

The 1966 text of Derrida did not say as much explicitly, but it practiced what it did not preach. In distinguishing nostalgic from affirmative modes of interpretation as two 'absolutely irreconcilable' options, it did not forget to add that 'we live them simultaneously and reconcile them in an obscure economy'. If that economy is obscure, it is doubtless because we are under its sway, as participants, contestants, even as we search for its rules.

If we think about the moment in the history of philosophy in which Derrida had to institute himself as a philosopher, back in 1966, and the institutional constraints that he had to overcome in the process, it becomes understandable why, in that moment, Derrida emphasized much more the affirmative aspect of interpretation. In later texts, though - such as Force of law, to which we will get back in a minute -, written after Derrida was established as a thinker and had even become, in some niches, part of the status quo, the ambiguous character of his view on interpretation became much clearer, with more emphasis given to the constraints exerted by instituted modes of reading. This does not mean, we should note, that Derrida's thinking has suffered some kind of “turn” during this period. On the contrary, we believe it has maintained the same spirit throughout his whole career. The change, as we have put it, is one of emphasis, and a purely strategic one.

Such an interpretation of Derrida's interpretation of interpretation, while defying certain preconceptions about the author, would put him, if he was a philosopher of law, not in the position of a legal realist or of what Dworkin (1986) would call an "external skeptic," but in a much more nuanced position that seems, in some ways, very close to Dworkin's own version of interpretation as both/neither finding and/nor inventing law - and yet quite different from it in its final consequences.

Actually, according to Weber (2001, p. 4), not even Nietzsche, who is frequently considered the great proponent of affirmation, could be simply put on the side of affirmative, happygo-lucky interpretative practice. Interpretation, in Nietzsche, is much less a lightheaded and 
free invention than it is a struggle, which means that the forces constraining creation must be taken as seriously as the power of creation itself.

The process of interpretation articulated by Nietzsche [...] applies not so much to what Derrida describes as the 'second' interpretation, the affirmation of play [...], as to the interpretive practice of which that description is a part, but only a part. [...] Beyond the 'irreducible difference' of nostalgic and affirmative interpretations, there is a third version, interpreting interpretation as a struggle to overwhelm and dislodge the already existing, dominant interpretation and thus to establish its own authority.

This third version of interpretation, that Weber attributes both to Nietzsche and to Derrida, and that he seems to set up in order to adopt as well, puts the idea of institution at the heart of the interpretative struggle, as every interpretation is always dependent both on the previous canons of interpretation that it seeks to replace and on its own power of rupture and creation through affirmation. In this process, no affirmation is possible that does not deal somehow with previously established constraints, and no hermeneutics that does not assume some degree of creative responsibility. Interpreters are always already in the middle of a game of institution, maintenance and deposition of interpretations, in relation to which they are never entirely free to affirm whatever interpretation they will, yet never entirely constrained.

\section{Closure (of law) and exclusion (OF Violence)}

Weber (2001) takes us back to Saussure (1995), who states that the value of signs in general is determined purely by differential relations to other signs. Later, Saussure qualifies his position, explaining that it is the signifier and the signified, while considered separately, that are determined by pure difference. The sign, however, "considered in its totality," is determined in a more positive way, not only by difference, but by a determined opposition. "The guarantee of this more stable relationship," Weber (2001, p. 7) emphasizes (as the term "institution" is important for his own project), "Saussure calls 'linguistic institution.'”

Here, Weber is investigating how it is that a system designed to make interpretation possible is instituted, how its moment of unfounded "mystical" foundation takes place. In Saussure (1995), the sign is formed by a relation between signifier and signified, which, as separate entities, can only be identified in a differential, negative manner - by their difference in relation to all others in the same category. The sign itself, though, which brings together signifier and signified, guarantees a much more determined relation of opposition between two specific terms, and is, in itself, considered as a positive fact. It is the property of Saussure's linguistic institution to (institute and) maintain the parallelism between these two orders of differences - signifier and signified: 
The question posed by Saussure's shift from the notion of difference to that of opposition thus acquires a new and important dimension; if the move is justified, it is because of something called 'linguistic institution' (or perhaps: the institution of language) which has, as its proper function and property, precisely 'to maintain the parallelism' between signifier and signified, and thus to guarantee the integrity and stability of the sign. (WEBER, 2001, p. 7).

It is interesting to notice, in passages such as this, expressions such as "institution," "to maintain," "to guarantee" - which could be put in relation to Benjamin's "Critique of violence" - and "integrity" - which takes us back to Dworkin. If law is to be interpreted as integrity (DWORKIN, 1986) - that is, as a more or less coherent body that can be defined because it can be limited -, this must depend on some moment in which law is instituted, founded as an institution, through the arbitrary establishment of certain relations and the equally arbitrary undercutting of other ones. This foundational moment must be "mystical" in the sense that Derrida (1992) extracts from Pascal and Montaigne, and it can be observed as well in law's institution as "integrity" as in the institution of a language. Both law as integrity and Saussurean langue must be instituted, maintained, and guaranteed by certain forces.

Nevertheless, how is this "mystical" institution operated? This is a question that - for the very reasons why the word "mystical" is used here - we will not be able to fully answer, even if we can say some things about (around) it. As Weber (2001, p. 8) points out (and this is perhaps the central point of his essay), in order to make possible a system called langue in relation to a community of speakers, both the community and the relevant practices must be arbitrarily separated from its others, i.e., whatever will be excluded. "The linguist must not merely observe certain phenomena," Weber writes, "he must also force himself to disregard others. [...] In order to regard, the linguist must disregard." Saussure must postulate a "unified collective consciousness" in order to construe language as a work of this consciousness, and yet this collective consciousness itself is founded in the same gesture that founds language, by forcefully and arbitrarily excluding that which is not taken into account.

Here, once again, the institution of langue parallels the institution of law, and it is perhaps Carl Schmitt who best described this necessary gesture of exclusion (and Weber is clearly aware of this connection). Schmitt argues that Law cannot be simply thought of as founded by the common will of the people, because there is no such thing as "a people" until an arbitrary separation is drawn between "us" and "the others" - friend and enemy as he puts it in The concept of the political (SCHMITT, 1992). Such a separation must be the product of a decision by a Sovereign, who thereby creates the people as people, so that law can be founded in its name. Such a community, then, does not precede law, but is founded in the very same gesture that founds law. 
It is for the same reason that Schmitt (1985, p. 5) famously defines the Sovereign as "he who decides on the exception." It is only by a sovereign decision that arbitrarily separates law from non-law (anomy, violence) that law can be founded. This is the gesture that Giorgio Agamben (1994) came to call exception in a very general and etymological sense - a gesture of the inclusion (capture) of something only through its exclusion. For Agamben (1998, p. 26), the gap between langue and parole, semiotics and semantics, meaning and application can only be bridged by such a violent gesture of exception. In Homo sacer, he writes:

The law has a regulative character and is a "rule" not because it commands and proscribes, but because it must first of all create the sphere of its own reference in real life and make that reference regular. Since the rule both stabilizes and presupposes the conditions of this reference, the originary structure of the rule is always of this kind: "If (a real case in point, e.g.: si membrum rupsit), then (juridical consequence, e.g.: talio esto)," in which a fact is included in the juridical order through its exclusion, and transgression seems to precede and determine the lawful case.

This, of course, in the field of law, amounts to taking the institution of law not as a historical and political process (institution as process of institution - that then gives place to maintenance and eventual destitution), but as a fact to be described (institution as a structure already in place), just as, in the case of linguistics, it "amounts to taking the 'institution of language' - language as institution for granted, as a given to be described rather than as a process to be understood" (WEBER, 2001, p. 9). In any case, the necessity of closure of the science as such violently depoliticizes the process it describes, by excluding its truly political moment. It is precisely this prior political moment that Benjamin (2011) tries to bring to light in his "Critique of violence," when he takes a step back in order to consider law in its deeper relation to violence, rather than simply describing it as a process already in course and already separated (through the institution of the pair means/ends) from illegitimate violence.

It is precisely this effort of neatly distinguishing law from violence that H. L. A. Hart (1994) undertakes in his classic book The concept of law when, against John Austin's definition of law as a command issued by a sovereign, he asks what it is that enables us to differentiate between a rule-governed system of coercion and a situation in which someone contingently seizes power and uses it to constrain others - Hart's classic example is that of a criminal who gives orders to a victim at gunpoint.

However, is the system of rule-governed procedures established by law able to guarantee a neat separation between law and violence? Fish (1989, p. 503) suggests that maybe "procedure rather than doing away with force merely masks it by attenuating it, by placing it behind a screen or series of screens." He points out that, after all, 
$[\ldots]$ the crucial question [...] still has to be asked: Who gets to make the rules? And once that question is answered, another question (it is really the same) waits behind it, who gets to say who gets to make the rules? If the answer to these questions turns out to be something like "whoever seizes the opportunity and makes it stick," then there is finally little to distinguish the rule centered legal system from the actions of the gunman; this gunman is merely better camouflaged. (FISH, 1989, p. 503)

If that should be the case, then the violence of law would risk being not only similar to the direct violence of the gunman, but in a certain sense more terrible. In Fish's (1989, p. 504) words, "here is a 'temporary' ascendancy of one person not only over another, but over many; here is a forceful capture even more sinister than that performed by the gunman because it wears the face of legitimate authority.” This self-legitimating, self-imposing institutional violence reminds us of Benjamin's (2011) greatest source of uneasiness, the violence he calls "mythical," and even of the ungraspable violence that we experience, in the work of Franz Kafka, as the expression of the twentieth century's worst nightmare. The way in which law seems to constantly balance in the border between legitimate, nonviolent procedure, and this Kafkaesque form of absurd violence is the problem we are dealing with here.

Interestingly, law's relation to pure force, in Hart, appears most directly in those cases when judges have discretion and must make law. "If this" (that judges, in some or all cases, make law), writes Fish (1989, p. 503), "is indeed the case, then the rule of law or, more precisely, the law of rule becomes an illusion, for the rule as a constraint, as a safeguard against casual violence, falls to the daily acts of violence committed by judges." Hart's insight (be it intentional or not) is, in Fish's (1989, p. 504) opinion, illuminating, since it brings forth the relation between force and interpretation:

The great merit of Hart's analysis is that it makes clear the close relationship - a relationship so close as to be one of identity - between the threat posed to law by force and the threat posed to law by interpretation; if it is the business of law to protect the individual from coercion that is random, unpredictable, and arbitrary, then the individual is no less at risk when he is at the mercy of an interpreting court than when he is at the mercy of an armed assailant. In both cases he is nakedly exposed to an agent who has seized authority and is in the accidental circumstance of being able to get away with it.

If the question of authority, in law and in law's interpretation, is ultimately a question of getting away with it, it is because only in retrospect can the institution of a certain law or of its dominant interpretation (two things that, in some ways, are very difficult to separate) be determined as either legitimate or illegitimate. If it were possible to catch whoever 
or whatever institutes a canon of interpretation in the act of instituting it, the act itself could never (if it really was an interpretative act) be simply recognized as legitimate; but once that moment has passed (and in practice it has always already passed), and if that foundation had been effective (felicitous, Derrida will say, referring to J. L. Austin), then it will had been (in retrospect) a legitimate foundation according to criteria it has itself instituted.

Fish sees, thus, The concept of law as Hart's best try at guaranteeing an intelligible and stable separation between law and force (interpretative included). Hart (1994, p. 132) does that by means of "the idea of a 'determinate rule," that is, one that does not require "a fresh judgment from case to case," and the related distinction between easy cases (that fall right into the "core" of the rule's meaning) and hard cases (that fall in a "zone of penumbra").

Fish (1989, p. 506) writes that, for Hart, "the foundations of law are linguistic" in a way that makes the determinacy of law as a possible non-violent institution dependent on the institution of a language that makes interpretation unproblematic - the "linguistic institution" Saussure tries to isolate. The concept of law as we know it, that is, as neatly distinct from violence, depends on (written) language's capability to communicate an invariable meaning, independently of interpretation, that is, impervious to interpretive force on the part of the interpreter, to creativity, to affirmative interpretation or play - at least in some cases.

That much seems to be true, even if Fish then associates Hart's theory with certain assumptions that could be called into question. According to Fish (1989, p. 506), in "the tradition in which Hart writes, [...] there must be a mode of communication that is general, not tied to the linguistic system of any particular community," and "once produced, these general communications must be understandable by anyone, no matter what his individual educational or cultural experience." It could be doubted that Fish's interpretation does justice to Hart. We wouldn't discard the possibility of interpreting his theory simply in terms of a language which rules are widespread enough within certain spaces of a certain society so that its members would, at least in some cases, be unable to interpret it in any way other than the one, established way to do so. This in itself - the idea that any society could institute a language so uniform that, in the relevant majority of cases, such a language would guarantee direct, non-interpretative communication - is already sufficiently problematic, even if it is, at the same time, quite obvious in some areas of practical life.

In fact, it is clear that in most historical situations our language and our interpretive criteria for law are sufficiently stable as to permit many cases to be regarded as easy. The recognition that interpretive force is constrained only by a mechanism that is itself product of an arbitrary force in no way implies that this mechanism is always apparent to us or that it can be simply removed as soon as we decide it should be (Fish clearly agrees with this, and so it is unclear why he rejects Hart so harshly). What we have been trying to 
understand, from the beginning of this paper, is precisely how these constraints, even if they are based upon no solid ground, still manage to institute and maintain themselves as legitimate criteria for the recognition and interpretation of law. Variably clear ways of distinguishing law from violence are usually available, and we are always already thrown within their context. At many times, as Derrida (1992) shows us, it is both possible and a condition of justice to destabilize this mechanism; but at many other times (many of which overlap with the first ones) it is also a condition of justice that we be able to apply it as and through law, to "calculate" with law, that is, to keep its mechanism working soundly.

We should, then, be careful not to fall too easily back into a simple rejection of law as violence or a simple acceptance of any institutionally-determined criterion for the separation of both terms. In the following and final section, we will consider how the role of institution and interpretation that we have been discussing fits into Derrida's treatment of the relation between violence and readability in Force of law. By doing that, we shall not resolve the ambiguity maintained until now from the beginning of this paper, but rather try to make that ambiguity and its dynamics as clear as possible, so as to better observe them.

\section{AN IMPOSSIBLE CLOSURE}

Constant vigilance is the only remaining project (if it can be called that) once any possibility of pure rupture, pure foundation, or a "final solution" is deemed inaccessible. Such vigilance does not, of course, imply a "scorched earth" strategy - the undoing of all and every structure until there is nothing left. In legal theory, it certainly should not mean the rejection of all legitimacy, interpretability, applicability of law on the grounds of a simple identification of law and violence, as sometimes associated with Critical Legal Studies. After our exposition about the relations between institution (act of institution; posited institution) and interpretation, and the foundation of law via the exclusion of violence, we shall now get back to Derrida in order to read him as an author who, taking very seriously the constraining forces that act in law's functioning (not only as violent, but also as sometimes necessary for justice), neither simply rejects law as a machine in the hands of interest, nor surrenders to an "internal" point of view that would again hide law's roots in violence. As we will try to show, the very distinction between an "internal" and an "external" point of view over legal practice or theory must be put aside in order to understand this approach.

In the beginning of our discussion, as we saw the foundation of a new state and the destruction of the state as the two "temptations" of deconstruction, we also saw that, in Derrida's (1992, p. 38, italics ours) words, deconstruction could be compared to "a general strike or a revolution in regard to models, structures, but also modes of readability" "“yes and no", Derrida says, that is, never purely and only as a "temptation"); one has, according 
to him, "the right to suspend legitimating authority and all its norms of reading," and this right to disobedience will be exerted in a way that "will sometimes argue with the unreadable in order to found another order of reading." We had left most of these curious expressions - "modes of readability," "norms of reading," "to argue with the unreadable," "to found an order of reading" - unexplained. Now, as we approach this paper's closing, we shall go back to them.

In any situation of reading, there is always an order of reading that makes reading possible (and excludes other readings as impossible), with its set of norms of reading and the modes of readability that they enable - the "interpretative practices," Fish (1980) would say, available for a given community of interpreters. Law as such - if it is to have "easy cases," or to be interpretable "as integrity," or in any other way justified - must have a wellestablished order of reading, and this order must be instituted through an arbitrary "mystical" performative that separates law from non-law, that is, from illegitimate violence. This includes, of course, an "interpretive violence" - the arbitrary separation between possible, acceptable readings and impossible readings, readings to be considered violent, abusive, arbitrary, and so on.

However, one has the right, Derrida says, to suspend those norms of reading, to defy the available modes of readability, in a reading that, at least in advance, could only be called an impossible one. Such "revolutionary" reading - and this is what qualifies it as an event in the strictest sense used by Derrida - is, thus, something impossible that happens, that happens to happen, generating its own possibility après coup. This is why, in Political Theology, Schmitt (1985, p. 36) argues that the decision on the exception (on which law is founded) can only be properly understood in an analogy to the theological concept of the miracle, as he affirms that "all significant concepts of the modem theory of the state are secularized theological concepts." The French expression (which is used by Derrida and maintained in French in the American version) après coup is very telling too, since it brings to light the relation between the retroactive legitimation of any revolutionary interpretation and that of a coup d'Etat - the way in which it is a state (of possible reading) that is overthrown in favor of a new state (of possible reading), which provides its own legitimation retroactively. "Only the yet-to-come (avenir)," Derrida (1992, p. 36) writes,

[...] will produce intelligibility or interpretability of this law. [...] A 'successful' revolution, the 'successful foundation of a state,' will produce après coup what it was destined in advance to produce, namely, proper interpretative models to read in return, to give sense, necessity and above all legitimacy to the violence that has produced, among others, the interpretative model in question, that is, the discourse of its self-legitimation.

It is, thus, only after the fact, after the coup and de facto that the separation between law and violence "will have been" instituted, situating, of course, the irruptive moment 
of foundation - that in its event could neither be placed on the side of law nor on that of violence - inside law (or on the border that guarantees its non-relation to its outside), as its legitimate foundation, even if, from the point of view (that is to say, through the canons of interpretation, through the rules of reading) of the previous state, that foundational act would necessarily be regarded as impossible and unreadable (and even if it could be read, it would be only as a random act of violence). The sense in which the word "Gewalt" is understood here is switched from that of mere violence to the sense of legitimate power.

For Derrida (1992, p. 37), any "reading that founds something new [...] remains unreadable in regard to established canons and norms of reading," and "this unreadability of violence results from the very readability of a violence that belongs to what others would call the symbolic order of law." What does the latter sentence mean? The unreadability of the violence that institutes a new law "results from" the violent readability of law. Because law can only make itself readable through an instituting act of violence, it is the aftermath of this violence (the violence that maintains law, and that finally cannot be distinguished from the iteration of the foundational violence that precedes it) that maintains it as readable, and thus capable to enforce itself. Derrida seems to place this maintaining violence as the counterpart of the unreadable violence that founds new law - and, in the same gesture, must then overthrow law.

Therefore, we are back to the initial polarization. On one side, readability, enforceability of law, possibility of "easy cases," nostalgic interpretation of "integrity," "mythical” violence, separability of law and violence; on the other, unreadability, impossibility of interpretation or enforcement, affirmative play, "divine" violence, undecidability between law and violence. In addition, as we began by suggesting, the two sides of this polarization can never be pure, fully separated or simply decided between. Derrida (1992, p. 54) sums his point up the following way, as he approaches the final pages of his discussion of Benjamin's "Critique":

To be schematic, there are two violences, two competing Gewalten: on one side, decision (just, historical, political, and so on), justice beyond droit and the state, but without decidable knowledge; on the other, decidable knowledge and certainty in a realm that structurally remains that of the undecidable, of the mythic droit of the state. On one side the decision without decidable certainty, on the other the certainty of the undecidable but without decision. In any case, in one form or another, the undecidable is on each side, and is the violent condition of knowledge or action. But knowledge and action are always dissociated. (DERRIDA, 1992, p. 56).

Undecidability is on the side of law because it is propriety of language - the type of undecidability resulting from the irreconcilable difference between general rule and the singular case that preoccupied Hart as well as Schmitt. Because law is linguistic, is expressed 
through (interpretable, communicable) language, it is structurally undecidable. Decidability, on the other hand, is on the side of "divine" violence for the same reason that motivated Schmitt to identify the decision on the exception with the structure of the miracle. As Derrida (1992) points out, no strictly possible decision - one that could be based on a rational calculation or any procedure of the sort - is a decision in the strict sense, since to decide must be to freely (and therefore arbitrarily) create a rupture, which will also be a rupture with the canons of rationality on which it might otherwise have justified itself.

Still - and this is the aspect that now concerns us most -, in another sense, there is decidability on the side of the law and undecidability on the side of revolution. This is the sense of knowledge and readability, of readability as "decidable knowledge," and in this sense, decidability is related directly to what we have been discussing. The "mystical," miraculous decision that institutes a state of reading, as we have seen, cannot be read as such through any of the already available (in the moment of its irruption) modes of readability. It is, therefore, impossible for us to decide whether what we have before us is or is not the irruptive event of a revolution. But after a state of reading has retroactively defined its moment of foundation and its modes of maintenance, then it is always possible to know (decidably) its foundation as foundation, to know its continuity as continuity. It is only the "mythical" violence "of destiny" that can be known, in such a way that, in the dimension of possible, decidable knowledge, we can always point to it as determined, fatal and, as such, violent. The dimension of rupture, on the other hand, is always out of the reach of our knowledge - it depends, so to speak, on a leap of faith. Revolutionary violence depends on doing the impossible at each time, even if there is, of course, yet no rational account of that performance. Derrida is not, then, saying something like "law always transforms itself, but always continues the same," because the dimension of transformation is not describable as such. Derrida can only say - as long as he follows Wittgenstein's advice to remain silent about that which cannot be meaningfully said, and he does not always follow it -, like Benjamin, that law is fatal like destiny. He cannot affirm that there is a possibility of revolution - at least not in a constative mode. All he can do is suggest it either through metaphor or through performance, and, we believe, so he does many times. This is - on a side note - what saves deconstruction from an accusation of being a form of quietism; the fact that it does not directly assert revolution as possible does not mean it is not a thinking of revolution. At the same time, Derrida does not render impossible any "internal" theorization about law, or knowledge of law as an object, as long as there is always an institutional (of the act of institution and of the maintenance of the institution) violence that grants its possibility. He only reminds us, as it were, how this possible knowledge is never non-violent.

As Derrida puts it, then, decidability and undecidability are on both sides of the equation, and there is what we could call a "third" undecidability between those two sides, in every interpretation. All decisions, to the extent in which they are decisions in the strict 
sense, cannot be read or known as such; we cannot decide about their presence. And every act of calculation, interpretation or application that founds itself on the norms of an institution already in place (knowable, readable, legitimate), to the extent in which it is possible, rational, correct and so on, cannot be decisive in the sense of generating a rupture, of reconfiguring the split between that which is included and that which is excluded from the institution. The expression "to the extent in which" is important because, as we have seen, the two aspects in question, corresponding to the two interpretations of interpretation that we saw in Weber's account of deconstruction - affirmative (decisive, undecidable) and nostalgic (decidable but not decisive) - must coexist in every deconstructive reading, so that deconstruction can never be purely revolutionary and never purely lawful, but, precisely by introducing rupture in a negotiation with the institution's maintenance, is able to break into the self-reproducing cycle of any institution (be it language, law or another) and force it out of its axis.

Neither a purely affirmative and political interpretation of deconstruction, such as proposed by those who would simply want to debunk law as a representation of the interests of the powerful, nor a domesticated, purely hermeneutical version that would make it possible to accommodate deconstruction to liberal-democratic institutions can really allow for such an event - the deconstruction of law - to be thematized. The truly particular consequences of Derrida's thought for the very contemporary question of law and violence can only show themselves in the aporetic economy between hermeneutics and affirmation that we tried to describe in this paper.

\section{REFERENCES}

AGAMBEN, Giorgio. Homo sacer: sovereign power and bare life. Stanford: Meridian, 1998. Estado de exceção. São Paulo: Boitempo, 2004.

AUSTIN, J. L. How to do things with words. Cambridge: Harvard University Press, 1975.

BENJAMIN, Walter. Escritos sobre mito e linguagem. São Paulo: Editora 34, 2011.

CRITCHLEY, Simon. The Reader: Derrida among the philosophers. In: GOODRICH, Peter et al. Derrida and legal philosophy. New York: Palgrave Macmillan, 2008. 
DERRIDA, Jacques. L'écriture et la différence. Paris: Éditions du Seuil, 1967.

. Force of Law, the "mythical foundation of authority". In: CORNELL, Drucilla; ROSENFELD, Michel. Deconstruction and the possibility of justice. New York: Routledge, 1992.

DE VILLE, Jacques. Jacques Derrida: law as absolute hospitality. New York: Routledge, 2011.

DWORKIN, Ronald. Is There Truth in Interpretation? Law, Literature and History. Inaugural Frederic R. and Molly S. Kellogg Biennial Lecture on Jurisprudence in the Coolidge Auditorium of the Library of Congress. Washington, October 26, 2009. Available at: <http://www.youtube.com/watch?v=742JyiqLhuk>. Accessed: Feb. 5, 2016.

Law's empire. Cambridge: Harvard University Press, 1986.

. Law as interpretation. Texas Law Review, v. 60. Austin: University of Texas Press, 1982.

FISH, Stanley. Doing what comes naturally: change, rhetoric and the practice of theory in literary and legal studies. London: Duke University Press, 1989.

Is there a text in this class? The authority of interpretive communities. Cambridge: Harvard University Press, 1980.

GADAMER, Hans-Georg. Verdade e método. Petrópolis: Vozes, 1999.

HART, H. L. A. The concept of law. Oxford: Clarendon Press, 1994.

SAUSSURE, Ferdinand de. Cours de linguistique générale. Paris: Éditions Payot et \& Rivages, 1995.

SCHMITT, Carl. Political theology. Cambridge: MIT Press, 1985.

O conceito do político. Petrópolis: Vozes, 1992.

SOREL, Georges. Réflexions sur la violence. Paris: Marcel Rivière et Cie, 1972.

WEBER, Samuel. Institution and interpretation: expanded edition. Stanford: Stanford University Press, 2001. 
LAW, INSTITUTIONS, AND INTERPRETATION IN JACQUES DERRIDA : 607

Juliana Neuenschwander Magalhães

PhD IN LAW FROM UFMG. PhD IN LAW FROM UNIVERSITÀ del Salento, Italy. Associate Professor at UFRJ.

RESEARCHER (1D) AT CNPQ.

jneuewanderlayahoo.com.br

José Antonio Rego Magalhães

MASTER'S degree in LAW FROM UFRJ. FAPERJ FeLlow.

jamagalhaes22Agmail.com 